\title{
OBITUARY
}

\section{DR. HENRY GEORGE FARMER}

Dr. Farmer, who died on 30th December, 1965, less than three weeks short of his 84th birthday, was both a musician and an ardent student, a combination which equipped him admirably for his scholarly activities. He was born in Ireland. As a young man he joined the Royal Artillery Orchestra in London, playing the violin and clarinet, and later becoming principal horn player. He early showed an interest in writing, publishing Memoirs of the Royal Artillery Band in 1904, and Military music and its story in 1912. In 1910 he became an orchestral conductor and some years later went to Glasgow where he was conductor of the Empire Theatre orchestra for over thirty years. This post gave him time for study, as his duties at the theatre, apart from a rehearsal on Monday mornings, were in the evening. He became a student at Glasgow University, studying Arabic under Dr. T. H. Weir, and graduated successively M.A., Ph.D., and D.Litt. He held a Carnegie Research Fellowship (1930-33) and a Leverhulme Research Fellowship (1933-35).

He had a remarkable fund of energy, as a result of which, while occupied with varied duties, he published many notable books and articles on Eastern music. His work $A$ history of Arabian music to the xiith century (1929) was an important scholarly contribution. The organ of the ancients (1931), based on Hebrew, Syriac, and Arabic sources, showed the wide extent of his researches. A very important work was his volume The sources of Arabian music (1940). It gave an account of all Arabic works, whether extant or known only through reference in other works, which dealt with any aspect of music. A second enlarged edition (1965) appeared shortly before his death. Although the index of this edition is rather scanty, the information which the work provides is invaluable. This most important bibliographical work indicates its author's untiring diligence in research, for it mentions not only works devoted directly to music, but also others which happen to include a discussion of some musical topic.

In 1921 Farmer joined the Royal Asiatic Society, and became a frequent and valued contributor to the Journal. He published a number of his articles in a series of volumes with the title Collection of Oriental writers on music, and others were published in his volumes entitled Studies in Oriental musical instruments $(1931,1939)$. He published many musical articles in the Encyclopaedia of Islam, and made important contributions to Grove's Dictionary of music and musicians (1954) and the New Oxford history of music. The publication in Leipzig of a posthumous contribution of his, Musikgeschichte in Bildern, is expected in the autumn of this year. Farmer joined Glasgow University Oriental Society in 1921, and contributed frequently to its Transactions. He was a member of the committee for 40 years and had been vice-president since 1947 .

While his contributions to the study of Oriental music gained him a world-wide reputation, he had many other interests. He identified himself with Scottish musical affairs and served them in various ways. He was founder and conductor of the Glasgow Symphony Orchestra. He served for a time on the B.B.C.'s Scottish Advisory Committee on Music. He founded the Scottish Musicians' Benevolent Fund, and over the years raised large sums for charity through his concerts. He published An old Scottish Violin Tutor (1931), Music in 18th century Scotland (1946), A history of music in Scotland (1947), The Aberdeen 
Concerts, 1748-1801 (1950). At the same time he did not forget his early career, for he published his History of the Royal Artillery Band in 1954. For many years he acted as an assistant librarian in charge of the music collection in Glasgow University Library. Through his initiative the Library acquired a collection of a number of original musical MSS by important Scottish composers. It also received from him a gift of over 1,600 books and MSS. He donated to the Mitchell Library in Glasgow, the largest public reference library in Scotland, various pieces of sheet music and a number of manuscript copies of the late Frederick Lamond's compositions. These two libraries possess complete sets of Farmer's writings.

In 1932 he was the only British representative at the Cairo Conference of Arabian Music, at which he was elected president of the Commission of MSS and History. This congenial task he undertook with his usual vigour. In 1934 he delivered the Cramb Music Lectures at Glasgow University. In 1946 he accepted appointment to the Chair of Music in the King Fuad I University, Cairo, but later withdrew his acceptance. In 1949 he was awarded the honorary degree of Doctor of Music by Edinburgh University.

He had a notable and many-sided career of which his works will remain as a lasting memorial to his ability. He was a pleasant companion with a keen sense of humour. While he had no hesitation in expressing his opinion trenchantly when he felt criticism was necessary, his remarks left no sting. Where praise was deserved he was equally ready to express his approval, and many have reason to be grateful to him for the encouragement he gave them. He will be greatly missed.

JAMES ROBSON. 